\title{
The Frailties of Lebanese Democracy: Outcomes and Limits of the Confessional Framework
}

\section{Natalia Nahas Calfat*}

Abstract: Lebanon is frequently referred to as a model of a plural and stable democracy in the Middle East: a multi-ethnic and pluri-religious society that guarantees political representation through a power-sharing confessional framework. Numerous authors also see the consociational model as the best democratic alternative given such a high degree of domestic heterogeneity. However, by emphasising Lebanese stability vis-à-vis a troubled regional scenario, these positive perceptions have neglected some elements of how democracy actually works in Lebanon. In this article, I analyse two domestic dimensions that hinder the success of the Lebanese democratic experience (the pre-attribution of seats and distortions of representation) and point to the limits, effects and consequences of consociationalism in this specific confessional reality. The results of this case study indicate that highly institutionalised consociational arrangements can lead to sectarianism, institutional instability, clientelism, and state frailty. I also lay out some lessons and implications that can be derived from such a framework in terms of harmful sectarian narratives at both the local and regional levels.

Keywords: Consociationalism; Lebanon; Confessional Frameworks; Democratic Limits; Case Study.

Sectarian conflict in the Middle East today is the perpetuation of political rule via identity mobilization.

Nader Hashemi and Danny Poster (2017: 5)

\section{Introduction}

Lebanon is frequently referred to by scholars, and by conventional wisdom, as an example of consociational democracy in the Middle East. It is a multi-ethnic and pluri-religious society in which eleven officially recognised sects (Shia, Maronite, Druze, Sunni, Greek Orthodox, Greek Catholic, Alawite, Armenian Orthodox, Armenian Catholic, Evangelical Protestant, and Jew) are represented in the government's legislative and executive branch-

\footnotetext{
* University of São Paulo (USP), São Paulo-SP, Brazil; nnahascalfat@usp.br. ORCID iD 0000-0001-89601598.
} 
es, with full judicial autonomy for each sect. Lebanon contains one of the last Christian enclaves in the region, and religions coexist through a very particular confessional institutional framework (Salamé 1994; Barclay 2007). The country also enjoys levels of freedom, pluralism, and civil rights that are well ahead of other Arab countries (Makdisi and Marktanner 2009: 12). Despite an enduring civil war in neighbouring Syria since 2011 and increasing regional turmoil, Lebanon has been able to maintain stability, internal security, and the rule of law. In short, Lebanon is one of the only - if not the only - democracies in the Arab Middle East.

In spite of the troubled contemporary regional context, Lebanon is one of the few examples of democratic stability in the Middle East, and its political arrangement is an archetype of successful multiculturalism. In 2012, Patrice Paoli, the French Ambassador to Lebanon, hailed Lebanese democracy, freedom, and religious coexistence, stating that it had become a model to the region that 'could help resolve violent sectarian conflicts in the Middle East' (Naharnet 2012).

The Lebanese confessional system is characterised by the proportional distribution of political power among the different religious communities according to their demographic weight and geographic distribution. Such an arrangement refers directly to Arend Lijphart's consociational literature for deeply divided societies. In Lebanon, different groups' representation in the government is guaranteed along confessional lines. This is achieved by reserving a proportional number of high-level government offices, cabinet seats, legislative seats, and public employment to representatives of each religious community (Saliba 2010). This confessional arrangement is called muhasasah ta'ifyah.

Several authors (Barclay 2007; Rowell 2016; Somsen 2016) have argued that the survival of the Lebanese confessional system throughout the $20^{\text {th }}$ century has proved its efficiency and durability and ensured stability in Lebanon. Lebanon has also been able to accommodate new political elites in the post-civil war period, especially the Shia, which shows compromise and balance. Hezbollah's insertion into the system as a political party - which some originally feared would destroy this arrangement - has provided further evidence of the system's co-optation capacity and suitability for domestic reality, as they have abided by the rules of the confessional game.

However, the country has also witnessed an increase in tensions related to sectarianism and polarisation, and it has required substantial efforts to prevent the system from being contaminated by regional turmoil and extremist groups. Especially in the last decade, the country has faced constant institutional disruption and the intensification of sectarian tensions, even after the end of the civil war (1975-1990). Examples of these tensions include the governance crises in 2005 and 2008, the presidential vacuum from May 2014 to October 2016, and the persistent budget, energy, water, and waste disposal crises of 2015. The previous parliament postponed national elections three times since 2009, alleging security concerns regarding political instability and the war in Syria. In addition, Lebanon is frequently accused of having a fragile nation-state that is deficient in terms of its military defence, the promotion of social services, and the provision of public goods. The 2015 public uprisings - and the 2016 municipal election results, which saw large numbers 
of votes for grassroots anti-sectarian movements - demonstrated the public's discontent with Lebanese leaders' inability to effectively manage the country. How, then, should we understand Lebanon's current situation?

This article's main purpose is to reflect on the limits and deficiencies of the consociational system in confessional contexts. My research hypothesis is that the historical crystallisation of political representation on solely religious foundations can lead to adverse effects once it becomes highly institutionalised. This case study of Lebanon, considered an example of plural democracy for the Middle East, helps us identify the consequences and limitations of this highly specific and structured subtype of consociationalism: confessional consociationalism.

This brings us closer to the regional and specialised literature, which already criticises the confessional system's functioning in terms of religious representativeness and state efficiency (Krayem 1997; Petallides 2011). These authors demonstrate, additionally, that confessional consociationalism has many malaises and disorders, and generates institutional instability and sectarianism. Critics (Barry 1975; Assaf 2004; Makdisi and Marktanner 2009; Kingston 2013; Nelson 2013; Khatib 2015) argue that such systems entrench sectarian identities, freeze power among traditional elites, and foster clientelism on religious grounds. The Lebanese duality between a pluri-religious and tolerant model, on the one hand, and institutional instability and sectarian gridlock, on the other, is a result of its confessional institutional arrangement.

The first part of this article shows how the international literature categorises the Lebanese case as a consociational democracy and the extent to which this arrangement is still presented as beneficial for the country's internal stability. The second part analyses two internal dimensions that threaten the success of the Lebanese democratic experience: the confessional pre-attribution of seats and the resulting representative distortions. I wrap up the second part by exploring this system's specificities, how consociational assumptions are manifested in Lebanon, and their effects. Finally, the third part debates the implications of this scenario for state-of-the-art analysis on the Middle East, especially for analyses centred on sectarian narratives as the solution for allegedly primordial and endogenous conflicts and identities; this type of narrative has become more common since the invasion of Iraq in 2003 and the Arab Spring.

\section{The conventional wisdom: Lebanon as a consociational democracy}

Arend Lijphart's consociationalism is the political theory most commonly applied to fragmented and multi-confessional societies. This model predicts that political elites from different sects or subcultures - despite not sharing similar values - will agree and compromise under a pragmatic institutional arrangement, which will favour democratic stability and governance (Lijphart 1968). Parliamentary consociational democracy is designed to avoid sectarian conflicts and seeks to faithfully represent society's demographic composition - particularly in regard to religious and minority groups - within the state (Lijphart 1995). Such a design would be the most promising and realistic system for conflict man- 
agement, capable of creating and maintaining stability in deeply divided societies (Lijphart 1977: 236; Andeweg 2000; Assaf 2004), and it is frequently postulated as a solution for sub-national and religious conflicts in the Middle East. Despite criticisms related to democratic quality and vitality (Lustick 1997), consociationalism has proven to be effective and robust in several countries.

In Lebanon, the challenge of governing a society composed of 18 confessional communities while protecting minority rights and religious pluralism has taken the form of consociational confessionalism. It ensures the representation of groups in the government and state institutions along confessional-religious lines. The framework reserves a proportional number of high-level government offices and ministerial cabinets' posts for the respective representatives of the various religious communities, as well as the equitable distribution of parliamentary seats among them.

For decades, the country was considered a democratic model of peaceful inter-religious coexistence and co-operation for the Middle East - often referred to as 'the Switzerland of the East.' Between 1943, its year of independence, and the 1970s, Lebanon was regarded as a post-colonial success story, enjoying economic growth and a society frequently referred to as free and open. Up until 1975 (when civil war broke out, leaving 250000 dead), the literature was unanimous in stating that the consociational framework in Lebanon was a success (Lijphart 1977; Ehrlich 2000; Makdisi, Kiwan and Marktanner 2011; Nelson 2013). Lebanon, it is argued, is inherently pluralistic and tolerant, and its constitution, laws, and policies protect and respect religious freedom. Even as of 2011, despite occasional social clashes due to spillover from the conflict in Syria, there have been no reports of abuses against religious freedom by the government (Department of State (USA) 2011).

According to Sara Barclay, 'the consociational system is the only one that can accommodate the social and political needs of a country with such deeply rooted and closed confessional communities as we find in Lebanon today' (2007: 74). Salamé (1994) argues that confessional democracy in Lebanon has survived for half a century 'despite the dissatisfaction of the Muslim confessional elite, the attempts of the ruling confession to concentrate as much power as possible in its own hands', as well as the 'overt rejection of the system by new radical forces triggered by modernisation, and the constant interference by regional forces in the country's domestic affairs' (Salamé 1994: 102). The confessional system, argues Somsen (2016), has been protecting Lebanon from a chaotic and unstable regional setting. Indeed, Lebanon is currently one of the most stable countries in the region despite the turmoil in Iraq and its proximity to the war in Syria and the Islamic State. Therefore, the consociational arrangement seems, at first glance, to have fulfilled its goal of providing stability to Lebanon.

Historically, the confessional system has been continuously maintained since its Ottoman roots in the $19^{\text {th }}$ century (Makdisi 2000; Collelo 2003; Traboulsi 2012). Additionally, there are indications of post-war compromise through the political and economic rise of a new social group: the Shia. Previously marginalised, they obtained veto power in 2008 through Hezbollah, which is today a bona fide party involved in domestic politics 
(Hamzeh 2004; Wiegand 2009), defending Lebanon's constitution and procedural legitimacy. ${ }^{1}$ And, despite 'occasional crises, ${ }^{2}$ the system has for the most part been maintained since the independence of the country (Salamé 1994; Rowell 2016). Additionally, some argue the incorporation of new elites represents natural adjustments to the consociational system, which have led to greater stability (Assaf 2004).

According to Rowell, the Lebanese confessional system is not frail and unstable; in fact, it has survived throughout the $20^{\text {th }}$ century, thereby proving its efficiency and durability:

The sectarian client-patron networks that form the basis of Lebanon's political system, so often derided as weak and unstable, have in reality survived a World War (1939-45); three Arab-Israeli wars (1948, 1967, 1973); the rise of Jamal Abd al-Nasser (with its attendant frenzy of military coups elsewhere in the region); two civil wars (1958, 1975-90) and subsequent occupations by both Israel and Syria; three further rounds of fighting with Israel (1993, 1996, 2006); and now a civil war in neighbouring Syria; and have done so essentially unscathed and unchanged in any fundamental way (Rowell 2016: 3).

Although strongly critical of the consociational system in Lebanon, Makdisi and Marktanner (2009: 12) argue that 'the most beneficial outcome of Lebanon's consociational democracy is that it allowed for levels of freedom and civil rights that placed Lebanon well ahead of other Arab countries.' Likewise, although without sparing criticism, Ehrlich (2000: 459) asserts that the post-war system seeks to allow the sects to resolve their own affairs and maintain their own beliefs while subscribing to a common Lebanese identity. According to Makdisi, Kiwan and Marktanner (2011: 129), Lebanon has maintained a generally liberal and pluralist political environment with civil liberties, especially freedom of expression, even if the practice of consociational democracy, particularly in the postcivil war period, has been flawed. Lebanon's model has also offered - it is argued - a real opportunity for different religious communities to share power and express their views freely in debates on public policy, even if there are clear advantages for the three main religious communities: the Maronites, the Sunni, and the Shia (Makdisi, Kiwan and Marktanner 2011: 132).

Abdel-Kader also asserts that the system has provided a context in which 'national consciousness has emerged; inter-community cooperation has increased and political values have begun to flourish and to converge, even though the political system may not have aggressively promoted national integration in the post-war period. Emphasising mechanisms of close consultation, he argues that the Lebanese political system demands a high level of co-operation between different powers in order to maintain restraint and promote reconciliation in all matters that could provoke confessional discord or conflict (AbdelKader 2010: 12). 
Lebanon, therefore, is still often referred to as a model of plural and stable democracy in the Middle East. According to conventional wisdom, it guarantees the political representation of the country's sects through a confessional arrangement. Many authors who advocate the consociational model see it as the best alternative given Lebanon's high degree of internal heterogeneity. Despite a long civil war in neighbouring Syria, Lebanon has been able to maintain political stability. And, in a sense, this stability is only assured by its confessionalism, which prevents the country from descending in yet another civil war. As a result, Lebanese confessionalism is still seen in considerable segments of the literature as the most feasible political model, even if one takes into account a consociational trade-off between this guarantee of institutional order and the resulting deficits of democratic quality.

However, by emphasising, in particular, the general stability of the Lebanese political system in the face of a troubled regional scenario, positive perceptions of Lebanon have neglected domestic aspects: how its democracy actually works. From here on out, I will focus more on the real effects and limits of this confessional consociationalism. It will be demonstrated that interpretations that focus on the alleged exceptionality of Lebanon's continued democratic stability overlook important features of the country's internal affairs. The Lebanese confessional system's particularities (presented in Part 2) are precisely those elements responsible for the defects in Lebanon's democracy, and they have been overlooked by most of the scholars mentioned above.

\section{Beyond the conventional wisdom}

\section{Specificities of Lebanese confessionalism: outlining the threats to its success}

The process that led to Lebanon's institutionalisation of sectarianism has its origins in the $19^{\text {th }}$ century. In Lebanon, the division of state power and resources between different sects, as well as the judicial power granted to religious authorities, began with the Ottoman millet system, and was reinforced during the French Mandate, when privileges were granted mainly to Maronite Christian groups. From then onwards, confessional identity continued to be built and incorporated into the judicial and administrative structures of the Lebanese state (Chaoul 2015), causing constant political tensions. Under the Ottoman millet system, religious leaders of each community were responsible for the administration of their community, also performing some civil duties. Reigning over an empire that was incredibly diverse ethnically and religiously, the Ottomans relied on local feudal elites and community-entrenched dynasties to rule it. These political leaders, known as zuama, ${ }^{3}$ used their status to provide protection and patronage (wasta). In fact, some of these same dynasties constitute the same sectarian elites in present-day Lebanon and are part of the ruling elite coalition (Nelson 2013: 353). 'Lebanon indeed witnessed the first formal institutionalisation of communalism and sectarianism under Ottoman rule' (Jamali 2001: 284).

The 1926 constitution consolidated these consociational sectarian arrangements from the previous century (Assaf 2004: 211). Although the new state comprised a variety of 
confessional communities, the political system between 1920 and 1943 was already reinforcing the connection between politics and religion, and the parliamentary structure gave a position of prominence to the Christian majority (Abukhalil 1989: 53-55). The 1943 National Pact reinforced this stimulus to sectarianisation that had already been promoted by the French colonial empire during its Mandate for Syria and Lebanon in the 1920s. When the National Pact was signed, 'these sectarian elites naturally took up the mantle of national leadership. Political bosses bargained intensely for resources and positions for their communities' (Nelson 2013: 353).

The Taif Agreement, which was signed in 1989 in Saudi Arabia, again reproduced this sectarian system. The 2008 Doha Agreement, while correcting major sectarian imbalances and readjusting disproportionalities in representation, has once again ratified this system and institutionalised political representation based exclusively on a religioussectarian basis. Repeatedly, throughout national pacts and agreements in 1926, 1943, 1990 and 2008, 'the traditional patriarchal and communitarian system was transposed into the state system of confessionalism, rather than having structured a democratic rule of law' (Chaoul 2015). Taking into account the role played by sectarianism since the era of Ottoman dominance, this scenario has constituted, for more than a century, a trajectory that has reinforced the confessional structures within Lebanon's institutional design. In this sense, Johnson (2001) and Makdisi (2000) challenge the view that confessional conflict is a given in Lebanese history, or a mere political extension of endemic conflicts; this is significant for my analysis of sectarianism in the region below.

The Lebanese government is currently composed of a large national unity coalition that includes all parties from the March 8 and March 14 Alliances. Since 2005, the country has been polarised between, on the one side, the March 8 Coalition, which is led by Hezbollah and contains Amal, the Free Patriotic Movement, the Progressive Socialist Party, and is supported by Tehran and Damascus, and, on the other side, the March 14 Coalition, which is led by the son of Rafik Hariri, Saad Hariri, composed of the Future Movement, Lebanese Forces and Kataeb, and supported by Riyadh and Washington.

The Cedar Revolution, which increased polarisation after 2005, and the December 2006 sit-in protest from allies of March 8 (which requested more balanced political participation in the government), were signs of Hezbollah's demand for veto power. Major cabinet protests and a violent political crisis in May 2008 were the aftermath of what was considered to be a violation by the government of its strategic infrastructure in the fight against Israel. Being able to put forward its demands and obtain veto power in Doha 2008, Hezbollah was strengthened, and confessionalism deeply institutionalised. Iran, interested in countering Saudi influence in Lebanon, gave its full-fledged support to Hezbollah for their political and strategic demands.

The opposition, through the March 8 Alliance, sought to expand its share of power to a significant extent, especially at the expense of the traditional Maronite Christian elite and Sunni Muslims. With the threat of a decline in Sunni power in Lebanon, Saudi Arabia has established itself as a key supporter of the March 14 Alliance (Norton 2007), polarising Lebanese politics between Iranian and Saudi blocs and their respective regional alliances. 
With the reinforcement of Shia power, the Sunni allies of Saudi Arabia were further isolated, which partially explains the Saudi involvement in Lebanese affairs in 2017 that helped lead to Prime Minister Hariri's short-lived resignation in November. The Saudi presence and interference in Lebanon is not, however, new. Critics point out that the Saudi mediation of the Taif Agreement in 1989, although it allowed the seat ratio between Christians and Muslims to change from 6:5 to 5:5, was able to support its anti-Shia interests by maintaining $50 \%$ of seats for Christians (Izady 2016). In addition, Saudi Arabia, Israel, and the United States overtly condemn Hezbollah's weapons and, in the battle of narratives, classify it as a terrorist group and Iran as a state sponsor of terrorism.

March 8 and March 14 represent opposing political forces on the Lebanese spectrum; the former tends to concentrate Shia votes and the second Sunni (with both having the support of different Christian sects). Due to the pre-attribution of legislative seats and the solidification of political-sectarian identities, political actors have a limited ability to win votes from other religions other than launching multi-religion plural lists. The electoral system 'continues to militate against the emergence of cross-cutting political parties with the ability to challenge the regional power bases of Lebanon's traditional zu'ama, argues Ochsenwald et al. (2016). However, since its alliance with the Free Patriotic Movement and its victory against Israel in 2006, Hezbollah has increasingly begun to win political support beyond its sect and establish a national base. With its offensive against jihadist groups on the Lebanese border, Hezbollah has been winning more domestic support and consolidating its role, not only as a local player, but also as a regional power. The increasing cross-sectarian support for Hezbollah and its consolidation of power has diminished the strength of local Sunni political forces, which is seen as a threat to Saudi Arabia and its domestic allies. Since the 2003 invasion of Iraq, sectarian tensions have contributed to the rise of the Islamic State, which preyed on Sunni marginalisation to present itself as the restorer of Sunni pride (Khatib 2015).

As the above historical account shows, each of the major politically relevant communities in Lebanon today, Maronite, Sunni and Shia - although the system favours the Christian-Muslim duality - has veto power, forming a kind of Triumvirate (Johnson 2001), or Troika (Majed 2010). Therefore, all three pillars have bargaining, compromise, and decision-making powers in the cabinet, and the Shiite 'minority' has a veto over vital national matters. Segmental autonomy is guaranteed through confessions' jurisprudence, to which Muhanna (2013) refers, metaphorically, as de facto legislative and legal federalism - or quasi-religious federations, according to Saliba (2010). Concerning Lijphart's proportionality principle, it is applied 'in its effects' - albeit non-traditionally, through the legislative pre-attribution of confessional seats - via what Lijphart called the 'system of proportional representation predefined on a community or religious basis' (Lijphart 1977: 148).

Although for the most part present in the Lebanese case, Lijphart's consociational guidelines seem to have had deleterious effects, or at least limits, in Lebanon. This is because the domestic and specialised literature has lamented the effects of the consociational arrangement and denounced Lebanon's instability and gridlock, as well as the promotion of clientelism, the predominance of sectarian identities, and the weakness of the Leba- 
nese state. As opposed to the literature that emphasises Lebanon's stability and its system's salutary continuity, a focus on the internal dimensions that threaten the success of this democratic experience (the pre-attribution of seats and distortions of representation) will clarify the peculiarities of the confessional system, how it is related to consociationalism, and what its limits are. Supported by the domestic literature, which already points out the confessional framework's disorders, I will dampen the positive perceptions of Lebanon's system as an exportable model.

\section{(i) Pre-attribution of seats}

Modern Lebanon is a unitary, non-federative, multi-party republic with a parliamentary system of government. Under the Taif Agreement of 1990, parliamentary seats are currently shared equally among Christian and Muslim sects, replacing the earlier $1943 \mathrm{Na-}$ tional Pact, which favoured Christians by a ratio of 6:5. By means of an unwritten convention, the Lebanese political system divides political and public service jobs (muhassasa) on a confessional basis. Effectively, it shares political power between a Christian President (in practice, a Maronite); a Sunni Muslim premier; a legislature led by a Shia Muslim president of the parliament; an Eastern Orthodox deputy prime minister and vice-president of the parliament; and a Druze head of the military (Collelo 2003: 183; Harb 2006).

Article 95 of the constitution states that Christians and Muslims shall be represented equally in parliament; the cabinet (including ministries up to the level of secretary-general and general-directors); and in high-level public service positions (Saliba 2010). While not in the constitution, it is also tradition that key administrative offices also respect the 50:50 proportion (Majed 2010). This distribution of political power operates at both national and local levels of government, given that seats in parliament are distributed proportionately across all of Lebanon's regions and all three branches of government (Department of State (USA) 2011).

The 18 officially recognised religious groups are Sunnis, Shias, Maronites, Armenians (Catholics and Orthodox), Druze, Copts, Syriacs (Catholics and Orthodox), Alawites, Greeks (Melkite Catholics and Orthodox Antiochians), Jews, Assyrians, Protestants, Chaldean Catholics, Isma'ilis and Roman Catholics. They all have the right to deal with family law according to their own traditions and religious courts. Every legal, civil, and personal system is religiously governed, as well as a wide range of institutions and welfare associations. The government's resource allocations are also confessionally distributed. In other words, sects become the means for gaining access to government resources and public state services, and one's religious affiliation determines the extent of one's political rights and privileges (Saliba 2010).

Lebanon's constitution, enacted in 1926 during the French Mandate and modified by several subsequent amendments, provides for unicameral legislative power to be exercised by a 128-member National Assembly that is equally distributed among Christians and Muslims. The confessional composition of the legislature is 34 Maronites, 27 Sunnis, 27 Shia, 14 Greek Orthodox, 8 Greek Catholics, 8 Druze, 5 Armenian Orthodox, 2 Alawites, 1 Catholic Armenian, 1 Protestant, and 1 Christian minority. This amounts to 64 Muslim seats and 64 Christian seats, and the following percentages: the Maronites have $26.56 \%$ 
of the total seats; the Greek Orthodox 10.94\%; the Greek Catholics 6.25\%; the Armenian Orthodox 3.91\%; the Armenian Catholics 0.78\%; the Protestants 0.78\%; other Christians $0.78 \%$; the Sunni $21.09 \%$; the Shia 21.09\%; the Alawite 1.56\%; and the Druze $6.25 \%$. The parliament also reserves six seats for non-resident candidates, equally divided between Christians and Muslims (Article 112, Parliamentary Elections Law No. 44 2017).

Parliamentary seats are divided between fifteen electoral districts or Mohafazahs, which are in turn further divided into 27 sub-districts. The seats in each district are further divided according to sectarian religious representation, and representatives can only compete against their coreligionists (see Table 1). The 128 deputies represent the political preferences and religious diversity of their constituencies. Each of the 27 districts has a given number of parliamentary seats, which is determined by the district's population and confessional distribution. The peculiarity of the elaborate consociational calculus in Lebanon is that each district reserves seats for different religious groups, which ensures the representation of all minorities, regardless of electoral results. In other words, it provides electoral results that are structured exclusively along denominational lines.

Table 1: Regional distribution of parliamentary seats among the 11 sects

\begin{tabular}{|c|c|c|c|c|c|c|c|c|c|c|c|c|c|}
\hline & $\begin{array}{l}\text { Distribution of } \\
\text { parliamentary seats } \\
\text { among electoral districts }\end{array}$ & "E & $\frac{\pi}{5}$ & 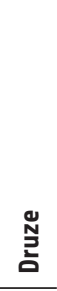 & 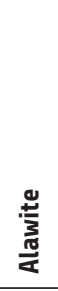 & 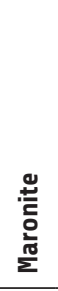 & 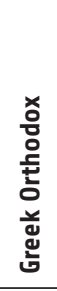 & 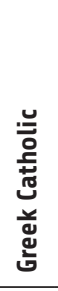 & 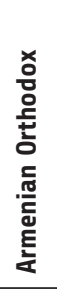 & 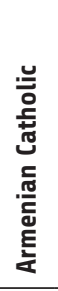 & 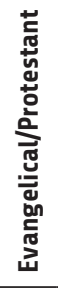 & 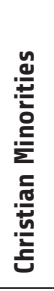 & 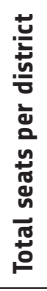 \\
\hline \multirow{8}{*}{$\begin{array}{l}\text { North } \\
\text { Lebanon } 28\end{array}$} & Akkar & 3 & & & 1 & 1 & 2 & & & & & & 7 \\
\hline & Tripoli & 5 & & & 1 & 1 & 1 & & & & & & 8 \\
\hline & Dinniyeh & 2 & & & & & & & & & & & 2 \\
\hline & Minnieh & 1 & & & & & & & & & & & 1 \\
\hline & Batrun & & & & & 2 & & & & & & & 2 \\
\hline & Bsharreh & & & & & 2 & & & & & & & 2 \\
\hline & Zgharta & & & & & 3 & & & & & & & 3 \\
\hline & Koura & & & & & & 3 & & & & & & 3 \\
\hline \multirow{6}{*}{$\begin{array}{l}\text { Mount } \\
\text { Lebanon } 35\end{array}$} & Jbeil & & 1 & & & 2 & & & & & & & 3 \\
\hline & Kisrawan & & & & & 5 & & & & & & & 5 \\
\hline & Metn & & & & & 4 & 2 & 1 & 1 & & & & 8 \\
\hline & Baabda & & 2 & 1 & & 3 & & & & & & & 6 \\
\hline & Aley & & & 2 & & 2 & 1 & & & & & & 5 \\
\hline & Chouf & 2 & & 2 & & 3 & & 1 & & & & & 8 \\
\hline \multirow{3}{*}{ Bekaa 23} & Baalbek + Hermel & 2 & 6 & & & 1 & & 1 & & & & & 10 \\
\hline & Zahleh & 1 & 1 & & & 1 & 1 & 2 & 1 & & & & 7 \\
\hline & West Bekaa + Rashaya & 2 & 1 & 1 & & 1 & 1 & & & & & & 6 \\
\hline
\end{tabular}




\begin{tabular}{|c|c|c|c|c|c|c|c|c|c|c|c|c|c|}
\hline & $\begin{array}{l}\text { Distribution of } \\
\text { parliamentary seats } \\
\text { among electoral districts }\end{array}$ & 突 & 莫 & ̃ㅗㄴ & 劳 & 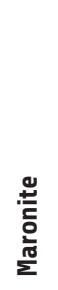 & 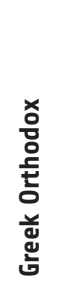 & 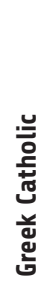 & 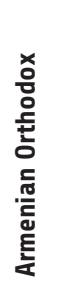 & 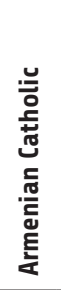 & 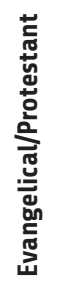 & 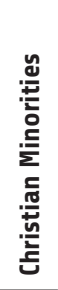 & 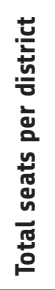 \\
\hline \multirow{2}{*}{ Beirut 19} & Beirut I & & & & & 1 & 1 & 1 & 3 & 1 & & 1 & 8 \\
\hline & Beirut II & 6 & 2 & 1 & & & 1 & & & & 1 & & 11 \\
\hline \multirow{7}{*}{$\begin{array}{l}\text { South } \\
\text { Lebanon } 23\end{array}$} & Saida & 2 & & & & & & & & & & & 2 \\
\hline & Jezzine & & & & & 2 & & 1 & & & & & 3 \\
\hline & Tyre & & 4 & & & & & & & & & & 4 \\
\hline & Zahrani (Saida Villages) & & 2 & & & & & 1 & & & & & 3 \\
\hline & Nabatiyeh & & 3 & & & & & & & & & & 3 \\
\hline & Bint Jbeil & & 3 & & & & & & & & & & 3 \\
\hline & Marjeyoun + Hasbaya & 1 & 2 & 1 & & & 1 & & & & & & 5 \\
\hline \multicolumn{2}{|c|}{ Total seats per confession } & 27 & 27 & 8 & 2 & 34 & 14 & 8 & 5 & 1 & 1 & 1 & 128 \\
\hline \multicolumn{2}{|c|}{ Total Muslims and Christians } & \multicolumn{4}{|c|}{64} & & & & 64 & & & & \\
\hline
\end{tabular}

Source: Parliamentary Elections Law No. 44, or Adwan law (2017).

\section{(ii) Distortions of representation}

This framework ensures that, even though Christians make up less than $30 \%$ of the population, according to unofficial estimates, ${ }^{4}$ exactly half of the parliament is made up of Christians (further divided into seven sects), while the other half is made up of Muslims (divided into four sects). Theoretically, this arrangement was designed to ensure that Lebanon's cosmopolitan and multi-religious composition was reflected in its political status quo. In practice, however, it structures and freezes political representation exclusively along religious lines and turns the state-citizen relationship into a state-client relationship.

According to Paul Kingston, the Lebanese do not vote in the neighbourhoods where they live. Instead, they must return to the district where their families were first registered in the 1930s. Such movement reifies the communal bond and entrenches the electoral power of regionally based family elites, whose support was especially cultivated as a French Mandate policy, in areas such as the North, the Bekaa Valley and the South (Kingston 2013: 29). In order for the state to capture and empower land-owning elites, the Mandate created these electoral laws in 1926, which mostly persist to this day as the current electoral system. Through these laws, 'constituencies were local $[\ldots]$ within which were multiple seats distributed on a communal basis - that deliberately privileged candidates of the leading local families' (Kingston 2013: 29). Voting along sectarian lines means discouraging voting for representatives who will not be responsible for development projects, 
zoning, or garbage collection where one lives. In the places where representatives do govern, they will not be responsive because their constituency lives elsewhere (Baker 2013).

This system leads to additional distortions, such as the under-representation of impoverished Shiite communities with weaker channelling of federal resources, which has contributed to their disproportional rates of poverty. Having undergone rapid demographic growth since the 1970s, with an estimated population between 40 and $60 \%$ of the country, and concentrated mainly in the periphery of Beirut and suburbs in the south of Lebanon, the Shias maintain the political representation proportion under the Taif Agreement of $1990,{ }^{5}$ which grants $50 \%$ of the seats in parliament to all Muslims in the country in total (including Sunnis and Druze). ${ }^{6}$

As a result, the number of non-Christian seats in parliament is equal to that of Christians, even though the Christian population is smaller, not to mention in decline. In the 2011 elections, Christians totalled 38.22\% of voters and Muslims 61.62\% (Lebanese Information Center 2013: 13). The Sunnis have also been granted the same number of seats as the Shia (27 seats each, or $21.09 \%$ ), despite the latter being about twice as numerous as the former (Izady 2016). While the Shia have become the largest segment of the population, the presidency is still reserved for a Maronite and the office of Prime Minister for a Sunni. ${ }^{7}$

Inelasticity and disproportionalities engendered by the confessional system are underscored by specialised literature, but overlooked by conventional wisdom. Petallides, analysing the results of the 2009 parliamentary election, ${ }^{8}$ states that Lebanon 'has a roughly $11 \%$ deviation from proportionality; nearly twice our global baseline of $6.65 \%$.' These are interesting figures when considered in 'a country with a political system that is falling over itself to ensure proportional representation of different groups' (Petallides 2011: 4).

According to data from the Lebanese Association for Democratic Elections, the socalled 'voting power' map is not homogeneous throughout the country. By indicating the percentage of voters registered in each district out of the total number of voters in Lebanon and comparing it to the percentage of seats actually allocated to that district, the data indicate that certain electoral constituencies are under-represented (such as Akkar, Dinniyeh-Minnieh, Zgharta, Tyre, Nabatiyeh, and Bint Jbeil) while others are over-represented (such as Kisrawan, Koura, Beirute I, and Jezzine) (LADE 2015).

These under- and over-representations, when added up throughout the entire country and combined with a confessional framework, make these disproportionalities highly problematic, particularly for a country in which sectarian balance is maintained very tenuously. What appears to be a small distortion in representation becomes flaws and disproportionalities that cannot be ignored, and ultimately holds the country hostage to a rigid census monitoring (frozen since 1932), as well as making it subject to constant contestations over minor representation maladjustments. Furthermore, even if proportionality were to be guaranteed throughout all districts, it still would not be truly representative because measuring the population of each confessional sect can only be done by monitoring birthplace registries. In the vast majority of cases, this refers to the ancestral village of one's family, not where one lives nowadays. This mechanism completely ignores the significant migratory movements registered during the last six decades. ${ }^{9}$ 
Petallides argues that the system also allows for electoral voids, when in spite of the voting strength of one candidate, he might not be elected due to the pre-attribution of seats to other sects. 'These votes that are lost and sent into the electoral void decrease the proportionality of the election results and directly undermine voter preferences' (Petallides 2011: 4). Concerning the district magnitude (the number of legislative seats assigned to a district) the author argues ${ }^{10}$ that 'with 26 districts electing 128 representatives, Lebanon's average district magnitude is $4.2(\mathrm{M}=128 / 26)$, which is well below Lijphart's magical $\mathrm{M}=7$ threshold, where a legislature truly represents a microcosm of society' (Petallides 2011: 4). Representatives of minority Christian groups - such as Syriac Christians, who represent $0.9 \%$ of the population and are not included in the pre-attribution formula despite having served in a few high-ranking public offices, demand ministerial appointments reserved for their sect. Greater political access is sought, then, through further religious specification, which perpetuates this sectarian way of thinking.

\section{Limits: a particular and highly institutionalised type of consociationalism}

Although the Lebanese experiment with institutionalised pre-war consociationalism lasted just over thirty years, it was subjected to several violent ruptures of internal stability before collapsing completely in 1975. Despite the difficulties in measuring the effectiveness of any institutional design, consociational democracy in Lebanon should not be judged as to have performed satisfactorily over this time, despite what the literature tends to say. As Assaf (2004: 204) argues, the 'new post-war "improved" consociational system does not seem to have fulfilled its objective of creating endogenous democratic stability. In addition, the last decade of Lebanese history has been especially troubled. The Lebanese government, some argue, makes indiscriminate use of vetoes, falling into institutional paralysis, much more frequently than it uses consensus and co-operation.

It is true, however, that Lebanon's institutional framework has shown strong resilience. In spite of extensive external influence in the country during the $20^{\text {th }}$ century, Lebanon was able to maintain its national identity and sovereign state mainly because of its confessional framework. The importance of external influences and their interactions with the confessional balance cannot be overstated. They include the French Mandate's favouritism of the Maronites, as well as the 1958 US military presence upon President Chamoun's request, Chamoun having accused the United Arab Republic of interference. The Cold War played an important role in the ideological identification and the polarisation of domestic conflicts that had preceded the political crisis of 1958, when Lebanon was on the verge of a civil war. While Maronite Christians wanted Lebanon to remain allied with the western foreign powers, leftist, Nasserist, and Pan-Arab Muslims pressed the government to join the newly created UAR, which was aligned with other Arab countries and the Soviet Union (Ochsenwald et al. 2016).

The further increase in social and political polarisation incited by the entry of Palestinian refugees and guerrillas into Lebanon (after the expulsion of the Palestine Liberation Organisation from Jordan in the early 1970s), as well as the growth of the Lebanese Muslim population, meant that there was pressure for changes and for the redistribution 
of the country's confessional power. The Maronite Christians, however, refused, allying with the United States, Syria, and Israel (Faour et al. 2007). Syria's large-scale intervention in 1976 during the civil war sparked a more active Israeli involvement in Lebanese affairs, intervening on behalf of the Christians as the Israelis' main ally against the PLO. The 1982 Israeli siege of West Beirut led to the subsequent emergence of a number of insurgent Shiite groups, who counted on Iranian support, including Hezbollah. Multinational United Nations forces were also present during the war. The ceasefire was brokered in 1989 by a tripartite committee made up of Algeria, Morocco, and Saudi Arabia (Ochsenwald et al. 2016).

After the end of the war, the country fell under the reinforced patronage of two main regional actors: Syria (who only withdrew its troops after 29 years in 2005) and Saudi Arabia - represented locally by Hezbollah's domestic opponents, particularly the Future Movement, who served Riyadh's regional objectives in Syria and Lebanon (Salloukh 2014: 104). Hezbollah's intervention in the Syrian war started in 2012 and deepened in 2014 and was also part of a larger 'geopolitical battle between Saudi Arabia and Iran over regional supremacy [that was] unleashed in the aftermath of the US-led invasion and occupation of Iraq' (Salloukh 2014: 104). As had also happened during the Ottoman and French periods, local elites have allied with regional players and foreign powers to strengthen their own interests and agendas. Since the Syrian war, the proxy clash between Saudi Arabia and Iran has become, in Lebanon, an important microcosm of the region as a whole.

Regional tensions and interventions have been closely related to the disruptions in the Lebanese confessional system. More important than demographic concerns, political and economic inequalities between Muslims and Christians have been the main reason for the disruptions in the system. In the words of Yahya (2017: 4), sectarian societies 'often invite influence from outside countries through the sectarian communities over which those outside actors often hold sway, a dynamic facilitated by the political divisions within society. Moreover, sectarian identities, given how entrenched they are, can be manipulated and mobilised quite often, along with fear, in order to create a narrative for the regional interests at play.

Despite current agreement on the need to maintain the confessional system in place, the 'pre-established electoral proportionality', or what Lijphart (1977: 148) calls proportionality 'of effects', encourages the reinforcement of cleavages, generates clientelism, and weakens the state by insulating sectarian local elites. In spite of the pre-civil war reality, the consociationalists who bet on the primacy of current stability and pluralism also fail insofar as they ignore the shortcomings engendered by the institutional design itself.

Besides political instability and state inefficiency, the confessional system has been strongly criticised for promoting sectarianism and entrenching religious identities (Van Schendelen 1984; Lustick 1997; Assaf 2004; Makdisi and Marktanner 2009; Nelson 2013; Khatib 2015). Horowitz (1985) argues that consociationalism can lead to the reification of ethnic divisions, while Assaf (2004) argues that consociationalism in Lebanon has had divisive effects, has politicised and manipulated ethnicity, and has the inability to prevent the emergence of communal conflicts. Critics, additionally, underscore a limited conception of the state's role, the attribution of legislative functions to non-state institutions, 
and the political dominance of traditional Maronite and Sunni elites (Makdisi 1996; Harb 2006). Consociational democracy has also been criticised for perpetuating a weak state and institutionalising sectarian differences (Horowitz 1985; Makdisi and Marktanner 2009; Khatib 2015).

In confessional consociationalism, electoral stimuli are pre-established and calcify voters' identification as well as politicians' affiliation on a sectarian basis, which leads to electoral results that are structured exclusively along denominational lines. Despite the efforts for pluralistic representation, the distortions and inelasticity of the system ignore ideological changes and even migratory movements. As a result, they reify communal bonds and entrench the electoral power of regionally based elites. This type of powersharing system reinforces the idea that communal local leaders bargain for power within state institutions. Sectarian leaders become not only the sole representatives of their communities, but also the main providers of services, jobs, and security, even as they pursue their personal interests. This has established a long history of clientelistic networks (Majed 2017).

In Lebanon, segmental group autonomy is widely respected, and religious identities are entrenched and static, without cross-cutting cleavages. Minorities have mutual vetoes over one another, which leads to stalemate and inoperability more often than good governance. The proportionality principle and grand coalition governments, although they are supposedly broadly representative of all significant denominational segments, ultimately multiply such groups and promote the politicisation of religion. The guarantee that 18 different confessions and sub-confessions will be represented has become a way to encourage new representation demands from demographically insignificant minorities, and to ensure that voters' political affiliations are based solely on their religion. In practice, the longing for full representativeness in Lebanon has become a permanent barrier to the secularisation of politics.

Adjustments and recalibrations to the Lebanese pari passu model of consociationalism have indeed been made, such as: absorbing new, demanding elites and widening the grand coalition (mainly Sunni in the Taif Agreement and Shiite in the Doha Agreement); segmental autonomy; veto power; and different sects' seats guarantee (in Legislative and Executive branches). However, Lebanon still experiences constant institutional gridlock. In addition, the country is unable to manage public assets, clamp down on clientelism, or attend to generalised complaints of elitism and under-representation by different sects. According to the Arab Barometer II (2013), only $25.8 \%$ of the population trust the parliament, and $22.9 \%$ trust political parties. However, $95.5 \%$ believe there is corruption within the state's institutions and agencies, and $88 \%$ think that obtaining employment through connections is widespread (Atallah 2012: 19). ${ }^{11}$

This reality shows that the problem has much less to do with consociationalism's applicability to Lebanon than to the inflexible subtype of consociationalism practised there. When it was adopted in Lebanon, the institutional design took consociationalism to extremes. The issue does not lie with the depth of social cleavages in Lebanon, nor with irresolute individuals who are incapable of any form of pragmatism. Lebanese elites do not lack the ability to make rational decisions, but the institutional arrangements provide 
political benefits from maintaining sectarian practices and patronage mechanisms. The costs of these practices are low, which ends up maintaining the confessional political status quo. In confessional-consociational democracies, electoral stimuli are pre-established and calcify identification along sectarian lines, which freezes changes in identity patterns and discourages secularism and ideological change. The Lebanese system, given its highly rigid institutional characteristics, constrains electoral results, not allowing for large-scale change in preferences - even if they take place in society.

The second part of this article has exposed the system's particularities and showed how, through the pre-attribution of seats and distortions of representation, confessionalism in Lebanon has resulted in a highly institutionalised type of consociationalism, threatening the success of this democratic experience. This framework was outlined and scrutinised so as to demystify the conventional wisdom of Lebanon as a success story. This effort is important, not only for exposing the limits and deficiencies of consociationalism in its confessional subcategory, but also for laying out the implications of this scenario for power-sharing sectarian solutions in the region.

\section{Can sectarianism work in the Middle East?}

Consociationalism is an institutional framework that is suitable as a transitional (nonpermanent) power-sharing mechanism for conflict resolution and mediation. As one can see through the current case study, however, the rigid pre-attribution of seats can be highly detrimental. Consociational recommendations to tackle Middle Eastern crises reinforce a view of ethnic and religious identities as immutable, freezing them by promoting what Ashutosh Varshney (2014) calls a 'state imprisonment of identities.' Due to an essentialised view of religions in the Middle East, one's confession is seen as the most relevant element of highly diverse groups of people. Such perceptions of the other frequently ignore how sectarianism is not only a relatively recent construction, but has also been manipulated throughout the modern history of the Middle East, a practice that has been present from the Ottoman millets and the French presence in Lebanon to the civil war and the current polarisation between Sunnis and Shias, with Lebanon's March 8 and 14 Alliances serving as proxies of a Saudi-Iranian hostility.

Conflicts over the distribution of political and socio-economic power in the Middle East, whether domestic or geopolitical, have taken on a sectarian face, and an array of actors have instrumentalised sectarianism. Examples of geopolitical, institutional, and ideational drivers of sectarianism in contemporary Middle East include the Shia-centric state-building in post-2003 Iraq, the Gulf regimes' exploitation of identity and religious politics, the Islamic State, and the sectarianisation of the war in Syria (Wehrey 2017).

According to Younis's analysis of consociational political structures in post-war Iraq, 'the constitution and electoral framework adopted instituted many of Lijphart's recommendations, including proportional representation, federalism and a parliamentary system with a weak presidency.' However, this democratic framework has failed (Younis 2011: 1). Sectarian violence in the Middle East is frequently framed in terms of 'timeless ethno-sectarian divisions,' exacerbating the essentialisation of these 'other' societies. Far 
from such inelasticity, 'identities are heightened and politicised in response to social contexts' (Younis 2011: 2):

Many of the 'divided societies' that come under scrutiny by scholars or practitioners are in complex post-conflict situations, and there is a tendency to oversimplify the divisions in these societies by ascribing them to primordial ethnic or religious divisions. [...] Scholars need to recognize the multitude of factors that contribute towards civil conflict, and avoid the trap of seeing ethno-sectarian divisions as inevitable features of societies that seem intractably 'divided' [...] It is time for the consociational orthodoxy to be challenged (Younis 2011: 15).

Yahya (2017: 1-2) also argues that Lebanon and Iraq have similar sect- and ethnicbased power-sharing systems, and that these structures have empowered 'corrupt sectarian and ethnic leaders who have undermined the rights of all citizens.' Both countries staged popular protest and civil movements in the summer of 2015 against patronage politics and corruption, demanding the transcendence of ethno-sectarian politics. Both protests were triggered by crises in the provision of services, but later morphed into broader condemnations of the countries' political systems and underlying power-sharing arrangements (Yahya 2017: 2).

Likewise, Dalacoura states that 'the American handling of occupied Iraq has undermined the prospect of long-term democratisation by strengthening sectarian and ethnic divisions between Shi'is, Sunnis and Kurds, and indirectly encouraging the re-Islamization of Iraqi politics' (Dalacoura 2005: 971). In Iraq, Yahya argues, ethnicities have become the new elements around which a post-Saddam Hussein Iraq has been organised. 'The sectarian power-sharing system put in place went even further than that of Lebanon. Not only were senior government positions allocated according to sect, but each representative had two deputies from other ethno-sectarian groups.' This pattern was repeated throughout the government at multiple levels in Iraq (Yahya 2017: 4).

By allocating positions in the state according to sect or ethnic group, both the Lebanese and Iraqi constitutions encourage communities to resort to so-called primordial identities. These identities 'tend to trump other forms of association, whether ideological or political.' As a result, by 'reducing politics to questions of religion and identity, Iraq and Lebanon effectively established systems that allow for poor governance, the entrenchment of undemocratic practices, and patronage politics' (Yahya 2017: 4).

In the aftermath of the Syrian civil war, speculations have abounded over the country's future power structure. Syria, suggest policymakers, could find peace and stability by adopting a constitutional formula based on a confessional power-sharing system mirroring those of Iraq and Lebanon. Similar recommendations can be found in the literature on the Israeli-Palestinian conflict. But, as the Lebanese and Iraqi models have vividly shown, this 'method of short-term conflict resolution leads to long-term conflicts in the future, the unequal distribution of state resources, and the political marginalisation of many people (Khatib 2015). 
The instrumentalisation of religion is extremely frequent in the region due to the continuity of the sectarian discourse and, above all, due to de facto sectarian politics. As Makdisi (2000: 164-166) pointed out, sectarianism in Lebanon - and often in the entire Middle East - is more of a modern political construct than it is socially endogenous; after all, religious and sectarian identities were only politicised and institutionalised in the $19^{\text {th }}$ century (Majed 2016). Sectarianism concerns the institutionalisation or reinforcement of the politicisation of religious identities through historical state institutions. This sectarian narrative - and its political representation - are still strong in national imaginations and quickly emerge in the presence of overflowing regional conflicts. Al-Rasheed (2014) argues we 'should move away from a historical Sunni-Shi'a divide and focus on the abysmal strategies of patron-client dictatorships and economic inequality between and within various groups. A reconsideration of the so-called eternal confessional model of the Arab world is overdue.'

Hashemi and Poster (2017) also consider sectarianisation to be a process that informs all conflicts in the region, not a product of anciently rooted sectarian grievances or an old primordial and immutable force. The term sectarianism:

[... tends to imply a static given, a trans-historical force - an enduring and immutable characteristic of the Arab Islamic world from the seventh century until today. [...] Authoritarianism, not theology, is the critical factor that shapes the sectarianisation process. Authoritarian regimes in the Middle East have deliberately manipulated sectarian identities in various ways as a strategy for deflecting demands for political change and perpetuating their power. This antidemocratic political context is essential for understanding sectarian conflict in Muslim societies today, especially in those societies that contain a mix of Sunni and Shia populations (Hashemi and Poster 2017: 4-5).

\section{Final considerations}

Despite recognising that confessional consociationalism entrenches ethnic and sectarian identities over time, much of the international literature on democracy in Lebanon focuses on its final positive effects (i.e. the maintenance of a minimal degree of stability and a tolerable democratic deficit, which are together capable of avoiding a new civil war). The acceptance of the confessional framework as the best possible democratic alternative is also clear in the many proposals for electoral reform that demand greater proportionality, decentralisation, and female participation, but rarely address de-confessionalisation. In the end, despite Lebanese democracy's weaknesses, it is still the most stable and democratic country in the Arab Middle East. All things considered, the literature argues that the system should still be continued, albeit with minimal adjustments. However, this case analysis demonstrated otherwise. Indeed, Lebanon appears to be protected against a new 
civil war, but the country registers severe inelasticity, disproportionalities of representation, and institutional paralysis. Moreover, the juxtaposition of economic and sectarian elites in post-war politics makes political reforms even more difficult (Salloukh 2017:2).

Out of consociational countries, the Lebanese case study is significant because it embodies the particularities of consociational democracies, but also points towards the limits of consociational theory. When crystallisation reaches its apex, as in Lebanon, consociational democracy's mechanisms such as the segmental autonomy, minority veto, proportionality 'of effects', and grand coalitions, even if present, become insufficient for maintaining democratic stability, actual proportionality, and elite co-operation. The institutional trajectory experienced by Lebanon, which has gradually laid out and reinforced the power distribution between different confessions, ends up trying to correct any distortions and gridlocks through even more rigid pre-assignments of seats. Lebanon will only avoid having to constantly respect sectarian proportions, being taken hostage indefinitely by strict census controls, if a light is shone on the limits and effects of consociationalism in the country and, at the very least, a non-rigid consociational system is adopted.

The results of this study also should instigate debates on the analysis of and prescriptions for sectarian solutions to contemporary conflicts in the Middle East - one example that especially stands out is the Iraqi institutional design after 2003. Since its inception, argues Majed (2016), sectarianism has been consciously devised and used by political leaders and regional powers to either maintain their positions in power or to gain more of it. Additionally, local and regional leaders in the Middle East have frequently accentuated historic grievances. Identity politics' dynamics in the region are highly complex and multifaceted, so they should not be reduced to fixed cultural explanations or self-contained identities that pre-date sectarianism. As a result, 'the widespread analyses of sectarianism in the Arab region are mostly wrong, and are often resulting in policy prescriptions, such as consociational democracy, that are based on a wrong diagnosis' (Majed 2016).

In normative terms, confessional consociationalism robs the Lebanese of the capacity to be represented as citizens in a representative democracy instead of as believers of a certain faith. The process of naturalising an exclusively politico-religious form of identification does not allow for the flourishing or representation of nuance in political institutions. As a result, the system does not allow for the secularisation of the political and communal spheres, thereby not allowing citizenship to replace confessional identities. This inaccurate regional diagnosis, so explicit and acute in the Lebanese microcosm, is why noxious religious narratives and sectarian solutions still abound in the contemporary Middle East.

\section{Notes}

1. Much of the specialised literature underscores Hezbollah's partisan ideological inflection, pragmatic insertion into electoral disputes, and normalised parliamentary dynamics (Harb and Leenders 2005; Norton 2007; Karam 2010). In 2006, Hezbollah and the Christian Free Patriotic Movement also signed an understanding encouraging national dialogue and supporting consensual democracy.

2. Examples of the latest crises are: the 2005 Cedar Revolution and political demonstrations in Beirut that were triggered by the assassination of ex-Prime Minister Rafik Hariri; the 17-month political crisis in 2008 sparked by a government move to shut down Hezbollah's telecommunication and security network that 
spiralled out of control; and, in 2014, the 29-month institutional deadlock and full-fledged deficiency in public goods provision.

3. Zaim are defined as 'feudal political leaders' who perform services and personal favours, and whose power is based on the loyalty of their political clientele and the relationship maintained with state authorities (Karam 2010: 38). AbuKhalil (1989: 56-57) writes that this type of loyalty is traded for services and access to power brokers, with family status determining one's access to education and prominence (Abukhalil 1989: 74).

4. Since its independence in 1943, Lebanon has preferred not to conduct a population census due to fears that the results could tarnish its political formula. The last census, conducted in 1932 under the French Mandate, showed a total population of 785 543, with a Christian majority of 53\% (Chamie 1980).

5. By the time when modern Lebanon was founded, Shias had proportionately little influence on Lebanese politics. In the government, Shias were heavily under-represented in senior office appointments (Norton 1998).

6. The (unofficial) statistics on the current percentage of the Shia population range from $33 \%$ to $59.7 \%$ (Jamail 2006) of the country's population, which is estimated at 5851 000, excluding refugees. In 2009, out of all registered voters, Sunnis made up $27.16 \%$, Shias $26.32 \%$, Maronites $21.93 \%$, Greek Orthodox $7.62 \%$, and Druze 5.73\% (Majed 2010: 20).

7. Even though, as of 1990, the President of the Parliament has taken on more power (Johnson 2001).

8. The previous Legislature extended its mandate three times: on 31 May 2013 (for 17 months), on 5 November 2014 (for 31 months), and on 14 June 2017 (until 6 May 2018, when new elections took place).

9. In addition to internal migrations due to civil wars, 450000 UN-registered (mostly Sunni) Palestinian refugees and an additional 1011366 Syrian refugees (mostly Sunnis, but also Shias) live in Lebanon. They make up one-fifth of the country's population (UNHCR 2017).

10. Petallides works with the previous electoral law (No. 25 2008), which considers five provinces and 26 electoral districts.

11. Several non-governmental and transparency groups in Lebanon work towards strengthening accountability and electoral institutions, and combating nepotism and corruption.

\section{Acknowledgements}

The author would like to thank Dr Glauco Peres da Silva, Dr Salem Hikmat Nasser and Dr Paolo Ricci for their helpful advice and comments on this paper as well as the research project as a whole. Sincere thanks go to the anonymous reviewers for their helpful and constructive comments, as they greatly contributed to improving the final version of the paper. The author is also grateful to the editors for their generous comments and support during the review process. Finally, thanks are due to CAPES/PROEX for the research grant that made this research possible. The author, however, bears full responsibility for the paper.

\section{References}

Abdel-Kader, Nizar. 2010. 'Multiculturalism and democracy: Lebanon as a case study'. Lebanese National Defense 72 (4): 1-17.

Abukhalil, As'ad. 1989. 'The society and its environment.' In Thomas Collelo (ed), Lebanon: A Country Study. Washington: Library of Congress, pp. 39-86.

Al-Rasheed, Madawi. 2014. 'Middle East dictators feed sectarianism.' Al Monitor [online]. 15 December. At https://www.al-monitor.com/pulse/originals/2014/12/sectarianism-does-not-explainarab-world-turmoil.html [Accessed on 16 November 2017]. 
Andeweg, Rudy. 2000. 'Consociational democracy'. Annual Review of Political Science 3 (1): 509-536. Arab Barometer II. 2013. Arab Reform Initiative. Data Survey. At http://www.arabbarometer.org/ content/online-data-analysis [Accessed on 27 June 2017].

Assaf, Noura. 2004. Consociational Theory and Democratic Stability. A Re-examination Case Study: Lebanon. PhD thesis, University of Warwick, UK.

Atallah, Sami. 2012. Arab Barometer II - Lebanon Country Report. LCPS. Arab Reform Initiative. At http://arabbarometer.org/content/arab-barometer-ii-lebanon [Accessed on 27 June 2017].

Baker, Aryn. 2013. 'Lebanon's sects game: The problem with its Byzantine political system'. Time [online]. 9 April. At http://world.time.com/2013/04/09/lebanons-sects-game-the-problem-withits-byzantine-political-system/ [Accessed on 15 June 2016].

Barclay, Sara. 2007. Consociationalism in Lebanon. Master's thesis, University of Pennsylvania, USA. Barry, Brian. 1975. 'The consociational model and its dangers.' European Journal of Political Research 3 (4): 393-412.

Chamie, Joseph. 1980. 'Religious groups in Lebanon: A descriptive investigation.' International Journal of Middle East Studies 11 (2): 175-187.

Chaoul, Milhem. 2015. 'A Associação de Minorias: a fórmula libanesa.' Conference paper delivered at I Seminário Internacional Brasil-Líbano. Rio de Janeiro, Brazil, 25 November.

Collelo, Thomas. 2003. 'Lebanon: A country study.' In John Rolland (ed), Lebanon: Current Issues and Background. New York: Nova Publishers, pp. 29-198.

Dalacoura, Katerina. 2005. 'US democracy promotion in the Arab Middle East since 11 September 2001: A critique.' International Affairs 81(5): 963-979.

Ehrlich, Charles. 2000. 'Democratic alternatives to ethnic conflict: Consociationalism and neo-separatism.' Brooklyn Journal of International Law 26 (2): 447-484.

Faour, Ghaleb, Sébastien Velut and Éric Verdeil. 2007. Atlas du Liban. Territoires et Société. Beirut: Institut français du Proche-Orient.

Hamzeh, Ahmad. 2004. In the path of Hizbullah. New York: Syracuse University Press.

Harb, Imad. 2006. 'Lebanon's confessionalism: Problems and prospects.' United States Institute of Peace [online]. 30 March. At https://www.usip.org/publications/2006/03/lebanons-confessionalismproblems-and-prospects [Accessed on 6 January 2017].

Harb, Mona and Reinoud Leenders. 2005. 'Know thy enemy: Hizbullah, "terrorism" and the politics of perception.' Third World Quarterly 26 (1): 173-197.

Hashemi, Nader and Danny Poster (eds). 2017. Sectarianization: Mapping the New Politics of the Middle East. London: C. Hurst \& Co.

Horowitz, Donald. 1985. Ethnic Groups in Conflict. Berkeley: University of California Press.

Izady, Michael. 2016. 'Lebanon ethnic composition.' The Gulf Project 2000. School of International and Public Affairs. At http://gulf2000.columbia.edu/images/maps/Lebanon_Ethnic_lg.png [Accessed on 05 October 2016].

Jamail, Dahr. 2006. 'Hezbollah's transformation.' Asia Times [online]. 20 July. At http://www.atimes. com/atimes/Middle_East/HG20Ak02.html [Accessed on 19 June 2012].

Jamali, Dima. 2001. Administrative Reforms in Pluralistic Societies: The Case of Lebanon. PhD thesis, University of Kent, UK. 
Johnson, Michael. 2001. All Honourable Men: The Social Origins of War in Lebanon. London: IB Tauris.

Karam, Christian. 2010. Da Revolução Política ao Reformismo Socioeconômico: Hizballah, Islamonacionalismo e Economias de Rede no Líbano Pós Guerra. Master's thesis, Universidade de São Paulo, Brazil.

Khatib, Lina. 2015. 'Sectarianism is not part of solution for Syria.' Carnegie Middle East Center [online]. 13 May. At http://carnegie-mec.org/2015/05/13/sectarianism-is-not-part-of-solution-for-syria/i8hj [Accessed on 08 October 2015].

Kingston, Paul. 2013. Reproducing Sectarianism: Advocacy Networks and the Politics of Civil Society in Postwar Lebanon. New York: SUNY Press.

Krayem, Hassan. 1997. 'The Lebanese civil war and the Taif Agreement.' In Paul Salem (ed), Conflict Resolution in the Arab World: Selected Essays. Beirut: American University of Beirut, pp. 411-436.

Lebanese Association for Democratic Elections, LADE (LB). 2015. Vote Power Data Maps. Beirut. At http://lebanonelectiondata.org/vote_power.html [Accessed on 07 June 2015].

Lebanese Information Center, LIC (LB). 2013. The Lebanese Demographic Reality. Washington, DC. At http://www.lstatic.org/PDF/demographenglish.pdf [Accessed on 05 October 2016].

Lijphart, Arend. 1977. Democracy in Plural Societies: A Comparative Explanation. New Haven: Yale University Press.

1995. 'Multiethnic Democracy'. The Encyclopedia of Democracy 3: 853-865.

1968. The Politics of Accommodation: Pluralism and Democracy in the Netherlands. Berkeley: University of California Press.

Lustick, Ian. 1997. 'Lijphart, Lakatos, and Consociationalism.' World Politics 50 (1): 88-117.

Majed, Rima. 2016. 'In the Arab world, sectarianism is real, sects are not'. Al Jazeera [online]. 16 October. At http://www.aljazeera.com/news/2016/10/arab-world-sectarianism-realsects-161012110949666.html [Accessed on 15 May 2017].

2017. 'Why the Lebanese support the same sectarian leaders.' Al Jazeera [online]. 6 April. At http://www.aljazeera.com/indepth/features/2017/03/lebanese-support-sectarian-leaders-170312084011811.html [Accessed on 15 May 2017].

Majed, Ziad. 2010. 'Hezbollah and the Shiite community: From political confessionalization to confessional specialization.' Aspen Institute 11: 1-28.

Makdisi, Samir, Fadia Kiwan and Marcus Marktanner. 2011. 'Lebanon: The constrained democracy and its national impact.' In Ibrahim Elbadawi and Samir Makdisi (eds), Democracy in the Arab World: Explaining the Deficit. New York: Routledge.

Makdisi, Samir and Marcus Marktanner. 2009. 'Trapped by consociationalism: The case of Lebanon.' Topics in Middle Eastern and North African Economies 11: 1-15. At http://www.luc.edu/orgs/meea/ [Accessed on 14 June 2016].

Makdisi, Ussama. 1996. 'Reconstructing the nation-state: The modernity of sectarianism in Lebanon.' Middle East Report 200: 23-30.

2000. The Culture of Sectarianism: Community, History, and Violence in Nineteenth-Century Ottoman Lebanon. Los Angeles: University of California Press. 
Muhanna, Elias. 2013. 'Lebanon: Federal or unitary republic?' Qifa Nabki [online]. 22 January. At https://now.mmedia.me/lb/en/archive/lebanon_federal_or_unitary_republic [Accessed on 17 November 2016].

Naharnet [online]. 2012. 'Paoli on Bastille Day: Lebanon's democracy a model to be followed in region.' 14 July. At http://www.naharnet.com/stories/en/46640 [Accessed on 01 July 2017].

Nelson, Sally. 2013. 'Is Lebanon's confessional system sustainable?' Journal of Politics and International Studies 9: 332-387.

Norton, Augustus. 2007. Hezbollah: A Short History. Princeton: Princeton University Press. 1998. 'Hizballah: From radicalism to pragmatism?' Middle East Policy 5 (4): 147-158.

Ochsenwald, William, Samir Khalaf, Richard Barnett, Glenn Bugh, Clovis Maksoud and Paul Kingston. 2016. Lebanon. Constitutional framework. Encyclopedia Britannica [online]. At https:// global.britannica.com/place/Lebanon/Government-and-society [Accessed on 17 November 2016].

Parliamentary Elections Law No. 44 (LB). 2017. Official Gazette n. 27. Beirut. At http://aceproject. org/ero-en/regions/mideast/LB/lebanon-law-no.44-parliamentary-elections-2017/at_download/ file [Accessed on 13 February 2018].

Petallides, Constantine. 2011. 'Cedars to the East: A study of modern Lebanon.' Student Pulse 3 (12): 1-18. At http://www.studentpulse.com/a?id=603 [Accessed on 01 March 2016].

Rowell, Alex. 2016. 'The coming parliamentary stitch-up'. Now [online]. 20 May. At https://now. mmedia.me/lb/en/commentaryanalysis/567011-the-coming-parliamentary-stitch-up [Accessed on 07 June 2016].

Salame, Ghassan (ed). 1994. Democracy Without Democrats? The Renewal of Politics in the Muslim World. London: IB Tauris.

Saliba, Issam. 2010. 'Lebanon: Constitutional law and the political rights of religious communities' Library of Congress 12: 1-8. At https://www.loc.gov/law/help/lebanon-constitutional-law.php [Accessed on 05 October 2016].

Salloukh, Bassel. 2014. 'Lebanon - Where next for Hezbollah: Resistance or reform'. Conciliation Resources, Accord 1 (25): 100-104. At http://www.c-r.org/downloads/Accord25_Lebanon.pdf [Accessed on 10 June 2016].

2017. 'Sectarianism and consociational democracy: An interview with Dr. Bassel Salloukh.' The Lebanese Center for Policy Studies [online]. 12 June. At http://www.lcps-lebanon.org/agendaArticle.php?id=77 [Accessed on 26 June 2017].

Somsen, Hester. 2016. 'The rise \& fall of confessionalism in the Netherlands: Linkages to Lebanon' Lecture. The Issam Fares Institute, Beirut, LB, 14 March.

Traboulsi, Fawwaz. 2012. A History of Modern Lebanon. 2nd ed. London: Pluto Press.

United Nations High Commissioner for Refugees (UNHCR). 2017. Syria Regional Refugee Response. Genebra. At http://data.unhcr.org/syrianrefugees/country.php?id=122 [Accessed on 18 November 2017].

Department of State (USA). 2011. International Religious Freedom Report for 2011. Washington. At http://www.state.gov/documents/organization/193107.pdf [Accessed on 05 October 2016].

Van Schendelen, Rinus. 1984. 'The views of Arend Lijphart and collected criticisms'. Acta Politica 19 (1): 19-49. 
Varshney, Ashutosh. 2014. 'Consociational democracy and ethnic conflict'. Lecture 13 in the series Speaking of Ethnic Conflict: 18 Lectures by Ashutosh Varshney.' Conference lecture. Conflict Resolution Program, National Institute of Advanced Studies. Bengaluru, IN.

Wehrey, Frederic (ed) 2017. Beyond Sunni and Shia: The Roots of Sectarianism in a Changing Middle East. 1st ed. Oxford: Oxford University Press.

Wiegand, Krista. 2009. 'Reformation of a terrorist group: Hezbollah as a Lebanese political party' Studies in Conflict \& Terrorism 32 (8): 669-680.

Yahya, Maha. 2017. 'The summer of our discontent: Sects and citizens in Lebanon and Iraq.' Carnegie Middle East Center. [online]. 30 June. At http://carnegie-mec.org/2017/06/30/summer-of-ourdiscontent-sects-and-citizens-in-lebanon-and-iraq-pub-71396 [Accessed on 11 November 2017].

Younis, Nussaibah. 2011. 'Set up to fail: Consociational political structures in post-war Iraq, 20032010.' Contemporary Arab Affairs 4 (1): 1-18.

\section{About the author}

Natalia Nahas Calfat is a PhD student in Political Science at the University of São Paulo (USP) and holds a Master's degree in Political Science at the same university. The author is a member of the Research Group on the Middle East and the Muslim World (GTOMMM/ USP) and Executive-Editor of the Journal Malala (FFLCH/USP). She is a Teaching Fellow at IPSA USP Summer School in Methods and Concepts in Political Sciences and International Relations for Causal Case Studies and Process Tracing. The author is Director of National Affairs at the Institute of Arab Culture (ICArabe). Her research focuses on International Politics and conflicts, terrorism, confessionalism and power-sharing designs, post-colonialism in the Middle East, religious identity, and case studies.

\section{As Fragilidades da Democracia Libanesa: Resultados e Limites do Arranjo Confessional}

Resumo: O Líbano é frequentemente referenciado como um modelo de democracia plural e estável no Oriente Médio: uma sociedade multiétnica e plurirreligiosa que garantiria a representação política dos diferentes sectos presentes no país através de um arranjo confessional de partilha de poder. Inúmeros autores também enxergam neste modelo consociativo a melhor alternativa democrática, dado o alto grau de heterogeneidade interna. Contudo, ao frisarem a estabilidade libanesa ante o conturbado cenário regional, estas percepções positivas sobre o Líbano têm negligenciado alguns aspectos domésticos relativos ao real funcionamento desta democracia. Através da análise de duas dimensões internas que ameaçam o sucesso da experiência democrática libanesa (pré-atribuições de cargos e distorções repre- 
sentativas), este trabalho visa apontar os limites, efeitos e decorrências do consociativismo nesta específica realidade confessional. Os resultados obtidos através deste estudo de caso indicam que arranjos consociativos altamente institucionalizados podem engendrar sectarismo, instabilidade institucional, clientelismo e debilidade estatal. Ao cabo, este artigo também aponta as implicações e lições que podem ser derivadas do arranjo em termos das nocivas narrativas sectárias locais e regionais.

Palavras-chave: consociativismo; Líbano; sistema confessional; limites democráticos; estudo de caso.

Received on 3 August 2017, and approved for publication on 11 April 2018.

\section{(cc) BY-NC}

